8 Ownby RL, Crocco E, Acevedo A, John V, Loewenstein D. Depression and risk for Alzheimer disease: systematic review, meta-analysis, and metaregression analysis. Arch Gen Psychiatry 2006; 63: 530-8.

9 Woodward M, Oliphant J, Lowe G, Tunstall-Pedoe H. Contribution of contemporaneous risk factors to social inequality in coronary heart disease and all causes mortality. Prev Med 2003; 36: 561-8.

10 Wilson KC, Chen R, Taylor S, McCracken CF, Copeland JR. Socio-economic deprivation and the prevalence and prediction of depression in older community residents. The MRC-ALPHA Study. Br J Psychiatry 1999; 175: 549-53.

11 Almeida OP, Flicker L, Norman P, Hankey GJ, Vasikaran S, van Bockxmeer FM, Jamrozik K. Association of Cardiovascular Risk Factors and Disease With Depression in Later Life. Am J Geriatr Psychiatry 2006; 15: 506-13.

12 Chen R, Wei L, Hu Z, Qin X, Copeland JR, Hemingway H. Depression in olde people in rural China. Arch Intern Med 2005; 165: 2019-25.

13 Chen R, Copeland JR, Wei L. A meta-analysis of epidemiological studies in depression of older people in the People's Republic of China. Int J Geriatr Psychiatry 1999; 14: 821-30.

14 Chen R, Hu Z, Qin X, Xu X, Copeland JR. A community-based study of depression in older people in Hefei, China - the GMS-AGECAT prevalence, case validation and socio-economic correlates. Int J Geriatr Psychiatry 2004; 19: $407-13$.

15 Hu FB, Wang B, Chen C, Jin Y, Yang J, Stampfer MJ, Xu X. Body mass index and cardiovascular risk factors in a rural Chinese population. Am J Epidemiol 2000; 151: 88-97.

16 Chen Z, Peto R, Collins R, MacMahon S, Lu J, Li W. Serum cholesterol concentration and coronary heart disease in population with low cholesterol concentrations. BMJ 1991; 303: 276-82.

17 Copeland JR, Prince M, Wilson KC, Dewey ME, Payne J, Gurland B. The Geriatric Mental State Examination in the 21st century. Int J Geriatr Psychiatry 2002; 17: 729-32.

18 Copeland JR, McCracken CF, Dewey ME, Wilson KC, Doran M, Gilmore C, Scott A, Larkin BA. Undifferentiated dementia, Alzheimer's disease and vascular dementia: age- and gender-related incidence in Liverpool. The MRC-ALPHA Study. Br J Psychiatry 1999; 175: 433-8.

19 Saunders PA, Copeland JR, Dewey ME, Davidson IA, McWilliam C, Sharma V Sullivan $\mathrm{Cl}$. Heavy drinking as a risk factor for depression and dementia in elderly men. Findings from the Liverpool longitudinal community study. Br J Psychiatry 1991; 159: 213-6.

20 Copeland JRM, Dewey ME, Griffiths-Jones HM. Dementia and depression in elderly persons: AGECAT compared with DSMII and pervasive illness. Int $J$ Geriatr Psychiatry 1990; 5: 47-51.

21 Copeland JR, Chen R, Dewey ME, McCracken CF, Gilmore C, Larkin B, Wilson $\mathrm{KC}$. Community-based case-control study of depression in older people. Cases and sub-cases from the MRC-ALPHA Study. Br J Psychiatry 1999; 175 $340-7$.

22 Liu J, Li S, Zhang WX, Chen CH. Assessment of computerized diagnostic system of Geriatric Mental State schedule shortened community version (GMS-AGECAT). China Psychol Health J 2001; 15: 220-2.

23 Kua EH. A community study of mental disorders in elderly Singaporean Chinese using the GMS-AGECAT package. Aust N Z J Psychiatry 1992; 26: 502-6.

24 American Psychiatric Association. Diagnostic and Statistical Manual of Mental Disorders (3rd edn) (DSM-III). APA, 1980.

25 American Psychiatric Association. Diagnostic and Statistical Manual of Mental Disorders (4th edn) (DSM-IV). APA, 1980.

26 Altman DG, Bland JM. Interaction revisited: the difference between two estimates. BMJ 2003; 326: 219.

27 Townsend P, Phillimore $\mathrm{P}$, Beattie A. Health and Deprivation: Inequality and the North. Croom Helm, 1988.

28 Wilson KC, Copeland JR, Taylor S, Donoghue J, McCracken CF. Natural history of pharmacotherapy of older depressed community residents. The MRC-ALPHA Study. Br J Psychiatry 1999; 175: 439-43.

29 Prince $M$, Acosta $D$, Chiu $H$, Scazufca $M$, Varghese M. Dementia diagnosis in developing countries: a cross-cultural validation study. Lancet 2003; 361 909-17.

30 Prince $M$, Acosta D, Chiu H, Copeland J, Dewey M, Scazufca M, Varghese M; 10/66 Dementia Research Group. Effects of education and culture on the validity of the Geriatric Mental State and its AGECAT algorithm. Br J Psychiatry 2004; 185: 429-36.

31 Chen R, Hu Z, Wei L, Qin X, Copeland JR. I. The relationship between syndromes of depression and dementia temporal? The MRC-ALPHA and Hefei-China studies. Psychol Med 2008; 23: 1-6.

\title{
Attachment theory and the psychiatrist-patient relationship
}

\section{Jeremy Holmes}

When subject to stress, threat or illness, humans seek an older wiser figure or 'secure base'. The patient comes to the psychiatrist in a state of arousal. An empathic response on the part of the doctor, with accurate verbal identification of emotion, produces assuagement of attachment behaviours, triggering 'vitality affects' and the beginnings of 'companionable exploration' - the reasons for coming and history of presenting symptoms. People with insecure attachment histories find this process problematic, typically 'deactivating' or 'hyperactivating' affect, or producing incoherence. Psychiatrists need to identify and understand this sequence of relational expectations and behaviours in themselves and their clients. 